\title{
Some Cytogenetic Methods for the Investigation of Insect Chromosomes and Their Implications for Research in Systematic Entomology 1
}

\author{
Yavuz Koçak ${ }^{2}$ and Atılay Yağmur Okutaner ${ }^{3}$
}

\begin{abstract}
The use of karyological studies in insects is of considerable significance. However, chromosome karyotyping has been hampered principally by: 1) the minute size of many insects, 2) the recovery of suitable tissues, 3 ) the small number of cells adequate for analyses 4) the smallness of the chromosomes in some groups, 5) the difficulty in obtaining satisfactory numbers of well-spread or dispersed metaphases, and 6) the determination of the best time of the year to carry out chromosome preparations using freshly collected material because the life history of many insects is still not well-known. Many attempts have been made to reduce these difficulties by developing novel karyological methods. These procedures can yield chromosome preparations applicable to a wide variety of insects. In this paper, we outline techniques for preparation and observation of chromosomes from insect cells. Also, implications of chromosome techniques on insect systematics are discussed.
\end{abstract}

Key Words: Chromosomes, methodology, insect, systematics, taxonomy

Insect chromosomes have been the subject of considerable research for more than a century (Gokhman and Kuznetsova 2006, Sadílek et al. 2016). As a main problem in entomological studies is the difficulty in identifying closely related species (Okiwelu and Noutcha 2014), chromosomal data have provided ample opportunities for taxonomic and phylogenetic analyses of many insect groups (Miao and Hua 2017, Soldán and Putz 2000). Cytogenetic studies have detected fundamental patterns in chromosome evolution that have assisted in the systematic analyses of many taxa (Camargo et al. 2006).

Although insects constitute some of the best models for cytogenetic studies, their chromosomes are often problematic. Cytologists have been greatly hampered in the study of insect chromosomes by the fact that some species possess small size and/or a high number of chromosomes which usually makes counting and observing individual chromosomes difficult. Therefore, remarkable research interest has been focused on the development of reliable and efficient

\footnotetext{
${ }^{1}$ Submitted on November 11, 2017. Accepted on November 16, 2017. Last revisions received on December 30, 2017.

${ }^{2}$ Corresponding author: Ahi Evran University, Faculty of Engineering and Architecture, Department of Environmental Engineering, 40100, Kırşehir. Turkey. E-mail: ykocak@ ahievran.edu.tr , ykocak80@gmail.com

${ }^{3}$ Ahi Evran University, Faculty of Arts and Sciences, Department of Anthropology, 40100, Kırşehir. Turkey. E-mail: atilayyagmur@gmail.com
}

DOI: 10.9784/LEB5(3)Kocak.01

Electronically available on December 30, 2017. 
cytogenetic techniques to generate good chromosome preparations, applicable to a wide variety of species and insect tissues (Sadílek et al. 2016). Observations of chromosomes, including banding patterns are usually made by locating cells in metaphase, the stage of cell division where chromosomes are greatly condensed and positions in the Equator of the dividing cells. These methodological improvements coupled with interest in comparative cytogenetics have produced abundant data on insect karyology.

The purpose of this paper is to present a review some of the currently available methods for preparing chromosomes that we have found useful in our own research. In our research, we use the conventional squash method with testes and, sometimes, midgut (Okutaner et al. 2011a, 2011b, 2011c, 2011d; Okutaner et al. 2012) as primary source of cells. It is not our intention to summarize wellknown works emphasizing cytogenetics and evolution (MacGregor 1993, White 1977) and/or cytological techniques (e.g., Barbosa et al. 2015, MacGregor et al. 1983, Sharma and Sharma 1980). Furthermore, this work highlights contributions of these methods to systematic entomology.

\section{Primary sources of cells for insect chromosome studies}

Many tissue sources have been used by cytogeneticists to obtain chromosome preparations from insect material with dividing cells. The advantages and disadvantages of these sources are discussed below.

Gonads (Testes and Ovaries). Preparation of metaphase spreads can be obtained from the gonads of live specimens (Popescu et al. 2000, Rozek 1994). Insect chromosomes are most easily studied in dividing cells in testes (Emmel 1968). The following characteristics favor such selection:

a. the structure of the insect testis, consisting of series of approximately parallel testicular tubes, tubules or follicles ranging in number from 1 to over 100 in which spermatozoa are matured, is very suitable for chromosomal studies because of its high incidence of meiotic and mitotic divisions and the loose arrangement of cells within insect testes (Resh and Cardé 2009, Roosen-Runge 1977, Wolf 1996),

b. the testes are easier to observe than the ovaries with the stereomicroscope (Popescu et al. 2000),

c. the male gonads have more dividing cells than the female gonads (Popescu et al. 2000),

d. meiosis continues in the testis mostly for a while after eclosion (Emmel 1968),

e. the haploid number of chromosomes is more easily observed than the diploid complement in mitotic somatic cells (Emmel 1968), and 
f. meiosis in the eggs of a female occurs severally during the short interval of sperm combination with each egg (Emmel 1968).

A drawback of using gonads is that it is difficult to determine the timing of active gametogenesis, which can occur either in the larval stages or in the adult. Therefore, as more preliminary tests are performed, more experiences are gained (Popescu et al. 2000).

Embryo Cells. Embryos are excellent sources of mitotic divisions (Resh and Cardé 2009). The best mitotic chromosomes can be obtained from dividing somatic cells in embryos. Although harvesting embryonic cells remains difficult in some species, it can also yield good chromosomes (Dutrillaux et al. 2006). Eggs with visible embryos are a good material source as well provided that their origin (whether embryonic or from the next generation) can be determined. Therefore, this method is used mainly when suitable insect breeding conditions are attainable (Popescu et al. 2000).

Mid-and Hindgut. An interesting alternative source of chromosomes for some insect species are mid- and hindgut cells (Bedo 1976, Dutrillaux et al. 2006). Of these, midgut cells undergo mitoses after feeding (Dutrillaux et al. 2006).

Other Tissues. Superior quality chromosome spreads have also been obtained from cerebral ganglia of third stage larvae of olive fruit fly Bactrocera oleae (Rossi, 1790) and gall fly Prececidochares utilis Stone, 1947 (Diptera: Tephritidae). Salivary glands, Malpighian tubules, rectum and fat bodies of flies (Diptera) are frequently used to obtain polytene chromosomes, the giant chromosomes that result from endomitosis, the repeated rounds of DNA replications without mitosis (Bedo 1976, Bush and Taylor 1969, Campos et al. 2003, Popescu et al. 2000, Tsoumani et al. 2013). Moreover, well-characterized mitotic chromosomes can be obtained from larval haemolymph cells or haemocytes (Baragańo 1978).

\section{Some cytogenetic methods for the investigation of insect chromosomes}

The use of chromosomal techniques has enabled the generation of data concerning the genome structure, chromosomal organization, and differentiation of many insect groups. The efficiency and success of these methods depend on the studied insect group.

Squash. Squash is the oldest method for spreading and flattening metaphase chromosomes (Pradeep et al. 2011). In most cytogenetic studies of insects, mitotic and meiotic chromosomes are obtained using the classical squash technique (de Souza 1991). In this technique, the tissue of interest is placed on a glass slide covered with a slide and gently compressed, or squashed, or tapped. Chromosome squashing is a rapid and straightforward way to visualize insect chromosomes (Chirino et al. 2014). This technique is particularly favorable where laboratory facilities are limited (Jovanović and Atkins 1969). 
However, squashing can damage preparations by introducing potentially destructive shear forces on chromosomes (Chirino et al. 2014). To obtain permanent preparations through this technique, it is necessary to remove the cover slip after freezing the slides in liquid nitrogen, but this could result in a considerable loss of cells and qualitative deterioration of material (de Souza 1991). Also, large amount of tissues adhering to the covering slip could be wasted. To avoid unnecessary loss of material, Rozek (1994) covered the slide with another slide and thus, one squash yielded two preparations. This is especially important for species with small gonads. During squashing, the cells are often concentrated in small areas resulting in clumping making it more difficult to produce well-spread preparations (Chirino et al. 2014). These problems seem connected to the fact that is not easy to apply the right pressure of the thumb during the squashing of the slide. Some workers use a flexible object, such as a pencil eraser to apply gentler pressure. Excessive pressure can bring about to the complete separation of the chromatids or can even break the chromosomes in fragments so as it is difficult to determine the exact centromere position and consequently the precise chromosomal morphology cannot be assessed. Moreover, with squashing it is more difficult to obtain preparations to be processed with the various cytochemical banding methods (Baldanza et al. 1991). In summary, ideally, cytogenetic preparations should have well-spaced chromosomes that are not distorted or stretched.

Conversely, if the tissue is fixed according to Rozek's protocol (1994) consisting of exposure to different fixatives (fixatives I, II, III and IV) composed of ethanol-glacial acetic acid-distilled water series at various proportions, good chromosome preparations with sufficiently spread cells could be obtained. These preparations with visible, distinguishable, and countable chromosomes are also suitable for various banding studies.

Aceto-orcein squash method. In earlier works, chromosome preparations were made using the aceto-orcein squash method. In this technique, the mitotic figures are not spread well, and the chromosomes are piled up, especially those species having large chromosome numbers, such as the ant Formica yessensis Wheeler, 1913 (Imai 1966).

Hyaluronidase-aceto-orcein squash method. This method gives favorable chromosome preparations for species having small chromosome numbers, such as the ant genera Pheidole, Monomorium, Aphaenogaster, Crematogaster, but it is less satisfactory for the species having more than forty or fifty chromosomes (Imai 1966).

Cell Suspension. This method is based on mitotic and meiotic cell suspensions in a glass tube and gives satisfactory and highly reproducible results. Prior to dissection, male and female individuals are treated with 0.05 to $0.1 \%$ colchicine in an insect saline solution at the proportion of $0.1 \mathrm{ml} / 5 \mathrm{~g}$ body weight for 6 to 8 hours. After pretreatment, gastric caeca, testes and ovaries are removed from the animals in insect saline solution, cleaned and sectioned in $5 \mathrm{ml}$ of 
hypotonic $0.075 \mathrm{M} \mathrm{KCl}$ solution until a cell suspension is obtained. The material is submitted to hypotonic treatment for 30 minutes at room temperature, and centrifuged at $800 \mathrm{rpm}$ for 5 minutes. After the supernatant is discarded, the remaining material is fixed three times in 3:1 ethanol: acetic acid. The material is resuspended in fresh fixative, and two drops of the suspension are added to a clean slide maintained in ice water, and air dried. The cell suspension method has been used to prepare chromosomes from species belonging to different insect genera, such as the orthopterans, Xyleus, Schistocerra, Abracris, Chromacris, and Tropidacris (de Souza 1991).

Cell suspensions for chromosome preparation have some limitations. This method uses embryonic cells (especially neuroblast cells obtained from eggs), material that most of the time is not available, forcing researchers to otherwise work with mitosis-rich adult insect tissues (de Souza 1991). Another disadvantage of the cell suspension method is the loss of material during centrifugation. Therefore, centrifugation should be used non-stop (e.g., $1300 \mathrm{rpm}$ for 10 minutes) to avoid cells attrition and loss of the material.

Cell Spreading. The cell spreading method can be used both on larger and smaller species of insects. This method resembles squashing, but it uses dissected tissues (e.g., ovarioles or the testicular follicles), one or two pieces of them per slide (de Souza 1991). Cell spreading facilitates the generation of flattened cells and consistent chromosomal dispersal, overcoming some of the disadvantages of squashing (Chirino et al. 2014). The entire material can be used without loss, usually observed with other methods (i.e., classical squash technique or suspension). This is particularly important when it is necessary to analyze many cells per individual or to prepare many slides per individual for the application of different cytogenetic techniques (de Souza 1991). The presence of cellular debris around of the chromosomes represents a drawback of cell spreading (Chirino et al. 2014).

Micro-Centrifugation and Micro-Spreading. This protocol combines controlled mechanical scattering, micro-centrifugation, and micro-spreading steps of smaller amounts (microliters) of male gonads. Using a single centrifugation microtube, excellent cytogenetic preparations from insect species, such as the reduviid kissing bug, Rhodnius prolixus Stål, 1859 and Triatoma lecticularia (Stål 1859) have been generated (Camargo et al. 2006). This method overcomes some of the drawbacks of the classical squash method (Camargo et al. 2006). Also, the technique of micro-centrifugation and micro-spreading has several additional advantages:

a. many slides per gonad can be obtained,

b. the amount of cellular dispersal can be controlled, and thus is useful if small clusters of cells at approximately the same stage of meiosis are desired, 
c. chromosomal spreads with desirable features are quite feasible for classical and molecular cytogenetics studies, and

d. very small amounts of material are sufficient to make cytogenetic preparations.

On the other hand, as far as we are aware, this technique has not been standardized for use in other species.

Flame-Drying. This method was developed as a slight modification of the techniques used in mammalian chromosome preparations. The protocol consists of flaming cell preparations and carefully passing the slide through a Bunsen burner. This procedure has been used to study all stages of meiosis in both testes and ovaries of insects, especially grasshoppers and locusts as well as mitosis from the brain cells of fourth instar larvae (prepupae) of mosquitoes. The flame drying method yields excellent preparations of chromosomes from either the gonads or somatic cells of both large and small insects without recourse to manual squashes or histological sections (Mukherjee and Cohen 1968). Imai (1966) also mentioned that the drying method in which the slide is dried by passing it through an alcohol flame is suitable for species of ants with many chromosomes. Since centrifuged cell suspension is dropped by a syringe on the wet surface of a pre-cleaned glass slide, metaphases are spread better than by the squash method. Thus, it is easier to see very fine chromosomes and to count the correct chromosome number. This method has yielded excellent mitotic figures, such as in the ant genera, Formica, Lasius, and Tetramorium. The flame drying method has one disadvantage: flame dried slides usually do not band well since this method may denature chromosomes (Shibab 2012).

Air-Drying. This method consists of dropping the fixed tissues on wet slides and allowing the material to air dry. The method has been used successfully with ants, beetles, and moths. Time-saving steps have been made resulting in a fast and easy method for field work. Cells undergoing meiosis or mitosis cells can be treated with colchicine to augment the precentage of cells in metaphase (Cokendolpher and Brown 1985). The air-drying method has numerous advantages (Cokendolpher and Brown 1985):

a. many slides from specimens of a single population or conspefics can be prepared simultaneously up to the point of cell dissociation,

b. properly scattered cell preparations are obtained without the use of enzymes, centrifugation, or cell resuspension,

c. no cover slips, dry ice, or liquid nitrogen is needed,

d. relatively permanent preparations, lasting at least one year, are available, if protected from dust and held at room temperature, 
e. preparations can be also used for banding techniques and banding pattern studies before they are stained, and

f. air-dried tissues result in preparations in which individual cells and their chromosomes are are well-spaced and suitable for counting (Cokendolpher and Brown 1985).

Air-drying has the disadvantage that it does not work well with small-sized insects, because this method needs a substantial number of mitotic cells (Imai 1966). Two variants of air drying, the drop method and air drying, and the scraping and air-drying are discussed below.

Drop Method and Air-Drying. This method was developed to obtain highquality chromosomal preparations of insect cells, especially dipterans (flies), without squashing or spreading. This protocol, which combines the drop and airdry techniques, produces a cell suspension with separated and mixed cells, producing clean chromosomal spreads with minimum overlap and clumping, and without damage and/or loss of chromosomes. The drop and air-drying method is preferred for quick and accurate cytogenetic studies, as well as to an improved procedure for the resolution of chromosome identification and characterization (Chirino et al. 2014). As far as we know, this method has only been used on dipteran cells.

Scraping and Air-Drying. This chromosome preparation technique, which has been successfully employed in both gastropod and lower vertebrate cells, was modified for the very small sized hymenopteran species, such as members of the families Aphelinidae and Eulophidae. Scraping and air-drying is simple, rapid, and reproducible. The technique consists of exposing the tissues to Shen solution $\left(\mathrm{NaCl}, \mathrm{KCl}, \mathrm{CaCl}_{2}\right.$ in distilled water at various concentrations) containing a colchicine-hypotonic solution, followed by centrifugation, fixation, dropping of the suspended cells on clean slides, and air-drying. This method has been used for the study of insect chromosomes, especially parasitic Hymenoptera, such as Encarsia berlesei (Howard, 1906) (Baldanza et al. 1991, Odiernea et al. 1993). The scraping and air-drying method has yielded very good results in organisms such as, Encarsia formosa Gahan, 1924, Encarsia luteola Howard, 1895, Encarsia hispida De Santis, 1948, and the eulophids, Thripobius javae (Girault, 1917), Baryscapus silvestrii Viggiani et Bernardo, 2006, and Pnigalio soemius (Walker, 1839) (Baldanza and Giorgini 2000; Caprio and Bernando 2006; Gebiola and Bernardo 2008; Giorgini et al. 2009, 2010). The metaphasic plates almost always showed chromosomes well-spaced, complete, and undistorted. Also, numerous specimens can be simultaneously processed and preparations, when protected from the dust and held at room temperature, are relatively stable for a great deal of time. Since many slides can be obtained from one specimen, some slides can be treated with various banding techniques (Baldanza et al. 1991). 
On the other hand, this technique has not been modified and adapted for single individuals; it requires groups of several specimens.

\section{The Use of Cytogenetical Methods in Systematic Entomology}

Morphological surveys provide the first data for systematic studies or any group (Munguira et al. 1995). However, morphological similarities highlight the opportunity to further study the cases using a multidisciplinary approach of which cytogenetic or karyologic studies constitute one of them. Karyological methods are much needed to further develop systematic entomology (Lifschitz et al. 1999). Cladistic analysis of those data, as well as other taxonomic considerations, have lead researchers to suggest the creation of formal classifications and phylogenies (e.g., Bickham and Carr 1983).

\section{The importance of selecting the right technique}

Not surprisingly, the wise choice of cytological technique is essential to achieve correct and consistent results. Below, we exemplify this by using reported cases.

Heteroptera. According to Angus et al. (2004), data on notonectid (Heteroptera: Notonectidae) chromosomes obtained by using serial sections have not revealed sufficient detail about the chromosomes' morphology. Instead, they illustrated the advantages of air-drying using four species of Notonecta. Airdrying yielded detailed information about their chromosomes, including their size, shape, and banding properties. The prepared karyotypes showed demonstrable differences between the species studied.

Coleoptera. Angus (1982) described two methods to prepare chromosome spreads from developing embryos of Helophorus (Coleoptera: Hydrophilidae). These methods were undertaken to compare the banded karyotypes of two species included in $H$. aquaticus (L.). The study of the chromosomes showed that these two forms are, in fact, good species, namely, $H$. aequalis Thomson, 1868 and $H$. aquaticus (Linnaeus, 1758). Virkki and Santiago-Blay (1997) showed chromosomal differences between two Puerto Rican allopatric populations of Diachus nothus (Welse) (Coleoptera: Cryptocephalinae) from the preparations obtained squashed testis. By the way, they noted that several constraints limit the use of conventional squash and air-drying techniques, especially in Diachus as they have small testes. Therefore, they highlighted the importance of developing the special techniques to microinject the embryos, located in fertilized eggs, with cell division retardants, such as colchicine.

Lepidoptera. Lukhtanov et al. (2006) stated that karyological analysis of the Agrodiaetus dolus (Hübner, 1823) species group (Lepidoptera: Lycaenidae) is difficult due to their extremely high chromosome numbers. The use of common squash and spread chromosome preparation techniques in these butterflies frequently yields inaccurate chromosome counts and may lead to erroneous taxonomic decisions. To overcome this problem, they used a modification of 
squashing that allowed them to examine investigate (non-squashed) metaphase plates and distinguish all chromosomes in the karyotype. While their karyological findings confirmed previous results obtained using the paraffin section technique, they were not able to confirm the published karyotype data obtained using the more modern squash method. Finally, they concluded that disagreement between their and formerly presented chromosomal data of this group depends on the karyological techniques preferred.

Hymenoptera. Pompolo and Takahashi (1986) studied the chromosome number and karyotype of two species of Polistes wasps by using a technique involving colchicine and sodium citrate pre-treatment of the cells. This rendered excellent quality metaphases that allowed a more precise chromosome identification, reliable determination of chromosome number, and morphology in both species studied.

Although rapid advances in molecular techniques provide a bewildering amount of data, traditional karyotyping methods remain useful, and they are relatively quick, simple, and inexpensive tools allowing the study of biodiversity. The obtained data facilitate the detection and identification of closely related taxa and the generation and/or testing of phylogenetic hypotheses (Gavrilov-Zimin 2011; Gokhman 1997, 2007; Marinho et al. 2014; Pyšek et al. 2013). One of the clearest examples of the value of cytogenetics in phylogenetic reconstructions is the case of primate evolution (Stanyon et al. 2008).

\section{Concluding Remarks}

Classical chromosome techniques are still one of the ways to gather data pertinent to systematic entomology. Insect cytogenetics is still in a survey period. The analyses of more karyotypes for taxonomic revision of many species groups is in order. Moreover, these methods further give impetus to undertake detailed karyological study of specific insect groups, particularly those of significant impact to humanity.

\section{Acknowledgments}

We thank five anonymous colleagues who reviewed this paper and offered constructive recommendations.

\section{Literature Cited}

Angus, R. B. 1982. Separation of two species standing as Helophorus aquaticus (L.) (Coleoptera, Hydrophilidae) by banded chromosome analysis. Systematic Entomology 7:265-281. http://dx.doi.org/10.1111/j.1365-3113.1982.tb00444.x

Angus, R. B., C. K. Kemeny, and E. L Wood. 2004. The C-banded karyotypes of the four British species of Notonecta L. (Heteroptera: Notonectidae). Hereditas 140(2):134-138. http://dx.doi.org/10.1111/j.1601-5223.2004.01815.x

Baldanza, F., G. Odierna, and G. Viggiani. 1991. A new method for studying chromosomes of parasitic Hymenoptera, used on Encarsia berlesei (Howard) (Hymenoptera: Aphelinidae). Bollettino del Laboratorio di Entomologia Agraria Filippo Silvestri 48:29-34.

Baldanza, F. and M. Giorgini. 2000. Karyotype and NOR localization differences between Encarsia formosa Gahan and Encarsia luteola Howard (Hymenoptera: Aphelinidae). Bollettino del Laboratorio di Entomologia Agraria Filippo Silvestri 56:33-41. 
Baragańo, R. 1978. Nuevo método para el estudio de cromosomas en Coleoptera a partir de hemocitos de estados larvarios. Boletín de Sanidad Vegetal - Plagas 4(1):23-33.

Barbosa, P., D. L. Berry, and C. S. Kary. 2015. Insect Histology. Practical Laboratory Techniques. John Wiley \& Sons. Ltd., Chichester, West Sussex, England, UK. 348 pp.

Bedo, D. G. 1976. Polytene chromosomes in pupal and adult blackflies (Diptera: Simuliidae). Chromosoma (Berlin, Germany) 57(4):387-396. https://doi.org/10.1007/BF00332162

Bickham, J. W. and J. L. Carr. 1983. Taxonomy and phylogeny of the higher categories of cryptodiran turtles based on a cladistic analysis of chromosomal data. Copeia 4:918-932. https://doi.org/10.2307/1445093

Bush, G. L. and S. C. Taylor. 1969. The cytogenetics of Procecidochares. I. The mitotic and polytene chromosomes of the Pamakani fly, P. utilis Stone (Tephritidae-Diptera). Caryologica 22(4):311321. https://doi.org/10.1080/00087114.1969.10796350

Camargo, M., M. A. Duque-Correa, and A. Berrio. 2006. A micro-spreading improvement for spermatogenic chromosomes from Triatominae (Hemiptera-Reduviidae). Memórias do Instituto Oswaldo Cruz, Rio de Janeiro 101(3):339-340. https://doi.org/10.1590/S0074$\underline{02762006000300021}$

Campos, J., C. F. S. Andrade, and S. M. R. Recco-Pimentel. 2003. A technique for preparing polytene chromosomes from Aedes aegypti (Diptera, Culicinae). Memórias do Instituto Oswaldo Cruz, Rio de Janeiro 98(3):387-390. https://doi.org/10.1590/S0074-02762003000300017

Caprio, E. and U. Bernardo. 2006. Karyotype of Thripobius javae (Girault) (Hymenoptera: Eulophidae). Bollettino del Laboratorio di Entomologia Agraria Filippo Silvestri 61:47-51.

Chirino, M. G., L. F. Rossi, M. J. Bressa, J. P. Luaces, and M. S. Merani. 2014. Dipteran chromosomes: A simple method for obtaining high quality chromosomal preparations. Current Science 107(11):1792-1794.

Cokendolpher, J. C. and J. D. Brown. 1985. Air-dry method for studying chromosomes of insects and arachnids. Entomological News 96(3):114-118.

De Souza, M. J. 1991. Two simple methods for the preparation of mitotic and meiotic chromosomes of Orthoptera. Revista Brasileira de Genética 14(4):1079-1084.

Dutrillaux, A. M., S. Moulin, and B. Dutrillaux. 2006. Use of meiotic pachytene stage of spermatocytes for karyotypic studies in insects. Chromosome Research 14(5):549-557. https://doi.org/10.1007/s10577-006-1052-7

Emmel, T. C. 1968. Methods for studying the chromosomes of Lepidoptera. Journal of Research on the Lepidoptera 7(1):23-28.

Gavrilov-Zimin, I. A. 2011. New cytogenetic data for some Palaearctic species of scale insects (Homoptera, Coccinea) with karyosystematic notes. Comparative Cytogenetics 5(5):375-390. https://doi.org/10.3897/compcytogen.v5i5.2116

Gebiola, M. and U. Bernardo. 2008. Karyotype of Baryscapus silvestrii Viggiani et Bernardo (Hymenoptera: Eulophidae). Bollettino del Laboratorio di Entomologia Agraria Filippo Silvestri 62:39-43.

Giorgini, M., M. M. Monti, E. Caprio, R. Stouthamer, and M. S. Hunter. 2009. Feminization and the collapse of haplodiploidy in an asexual parasitoid wasp harboring the bacterial symbiont Cardinium. Heredity 102:365-371. https://doi.org/10.1038/hdy.2008.135

Giorgini, M., U. Bernardo, M. M. Monti, A. G. Nappo, and M. Gebiola. 2010. Rickettsia symbionts cause parthenogenetic reproduction in the parasitoid wasp Pnigalio soemius (Hymenoptera: Eulophidae). Applied and Environmental Microbiology 76(8):2589-2599. https://doi.org/10.1128/AEM.03154-09

Gokhman, V. E. 1997. Chromosome number and other karyotypic features of parasitic wasps as a source of taxonomic information. Boletín de la Asociación Española de Entomología 21:53-60.

Gokhman, V. E. 2007. Karyosystematics of parasitic Hymenoptera: Taxonomic decisions at the species level. Comparative Cytogenetics 1(1):85-88.

Gokhman, V. E. and V. G. Kuznetsova. 2006. Comparative insect karyology: Current state and applications. Entomological Review 86(3):352-368. https://doi.org/10.1134/S0013873806030110

Imai, H. T. 1966. The chromosome observation techniques of ants and the chromosomes of Formicinae and Myrmicinae. Acta Hymenopterologica 2(3):119-131. 
Jovanović, V. and L. Atkins. 1969. A tissue culture technique for the study of avian chromosomes. The Auk 86(4):696-700. https://doi.org/10.2307/4083457

Lifschitz, E., F. Manso, and A. Basso. 1996. Karyotype study of the South American fruit-fly, Anastrepha fraterculus (Wied.) in Argentina. pp. 21-24. In, The South American fruit fly, Anastrepha fraterculus (Wied.); advances in artificial rearing, taxonomic status and biological studies. Proceedings of a Workshop Organized by the Joint FAO/IAEA Division of Nuclear Techniques in Food and Agriculture and held in Viña del Mar, Chile. 1-2 November 1996. 202 pp.

Lukhtanov, V. A., R. Vila, and N. P. Kandul. 2006. Rearrangement of the Agrodiaetus dolus species group (Lepidoptera, Lycaenidae) using a new cytological approach and molecular data. Insect Systematics \& Evolution 37(3): 325-334. http://dx.doi.org/10.1163/187631206788838563

MacGregor, H. C. 1993. An Introduction to Animal Cytogenetics. Chapman \& Hall. London, England, UK. 237 pp.

MacGregor, H. C. and J. M. Varley, with contributions by A. Bakken, and R. S. Hill. 1983. Working with Animal Chromosomes. John Wiley \& Sons. A Wiley-Interscience Publication. Chichester, England, UK. 250 pp.

Marinho, R. C., C. Mendes-Rodrigues, F. Balao, P. L. Ortiz, J. Yamagishi-Costa, A. M. Bonetti, and P. E. Oliveira. 2014. Do chromosome number reflect phylogeny? New counts for Bombacoideae and a review of Malvaceae s.l. American Journal of Botany 101(9):1456-1465. https://doi.org/10.3732/ajb.1400248

Miao, Y. and B. Hua. 2017. Cytogenetic comparison between Terrobittacus implicates and Bittacus planus (Mecoptera: Bittacidae) with some phylogenetic implications. Arthropod Systematics \& Phylogeny 75(2):175-183.

Mukherjee, A. B. and M. M. Cohen. 1968. A flame drying method for the investigation of insect chromosomes. Cytologia 33:565-567. https://doi.org/10.1508/cytologia.33.565

Munguira, M. L., J. Martin, and M. Peraz-Valiente. 1995. Karyology and distribution as tools in the taxonomy of Iberian Agrodiaetus butterflies (Lepidoptera: Lycaenidae). Nota Lepidopterologica 17(3/4):125-140.

Odierna, G., F. Baldanza, G. Aprea, and E. Olmo. 1993. Occurrence of G-banding in metaphase chromosomes of Encarsia berlesei (Hymenoptera: Aphelinidae). Genome 36(4):662-667. https://doi.org/10.1139/g93-088

Okiwelu, S. N. and M. A. E. Noutcha. 2014. The evolution of integrative insect systematics. Annual Research \& Review in Biology 4(14):2302-2317. https://doi.org/10.9734/ARRB/2014/7697

Okutaner, A. Y., H. Özdikmen, E. Yüksel, and Y. Koçak. 2011a. A cytogenetic study of Vadonia unipunctata (Coleoptera: Cerambycidae) and its distribution in Turkey. Florida Entomologist 94(4):795-799. https://doi.org/10.1653/024.094.0410

Okutaner, A. Y., H. Özdikmen, E. Yüksel, and Y. Koçak. 2011b. Some cytogenetic observations of two Dorcadion Dalman, 1817 species (Coleoptera: Cerambycidae: Lamiinae: Dorcadiini). Munis Entomology \& Zoology 6(2):866-876.

Okutaner, A. Y., H. Özdikmen, E. Yüksel, and Y. Koçak. 2011c. Some cytogenetic observations of Morimus orientalis Reitter, 1894 (Coleoptera: Cerambycidae: Lamiinae: Lamiini). Munis Entomology \& Zoology 6(2):912-919.

Okutaner, A. Y., H. Özdikmen, E. Yüksel, and Y. Koçak. 2011d. A synopsis of Turkish Certallini Fairmaire, 1864 with a cytogenetic observation (Coleoptera: Cerambycidae: Cerambycinae). Munis Entomology \& Zoology 6(2):937-943.

Okutaner, A. Y., H. Özdikmen, E. Yüksel, and Y. Koçak. 2012. Cytogenetic observations of Pachytodes erraticus (Coleoptera: Cerambycidae: Lepturinae: Lepturini). Florida Entomologist 95(3):731-736. https://doi.org/10.1653/024.095.0323

Pompolo, S. G. and Takahashi C. S. 1986. Karyotype of two species of wasps of the genus Polistes (Polistinae, Vespidae, Hymenoptera). Insectes Sociaux, Paris 33(2):142-148. https://doi.org/10.1007/BF02224594

Popescu, B., H. Hayes, and B. Dutrillaux. (Editors). 2000. Techniques in Animal Cytogenetics. Springer-Verlag Berlin Heidelberg. New York, NY, USA. 230 pp. https://doi.org/10.1007/9783-642-59711-4 
Pradeep, P. J., T. C. Srijaya, R. B. M. Zain, A. Papini, and A. K. Chatterji. 2011. A simple technique for chromosome preparation from embryonic tissues of teleosts for ploidy verification. Caryologia 64(2):235-241. https://doi.org/10.1080/00087114.2002.10589788

Pyšek, P., P. E. Hulme, L. A. Meyerson, G. F. Smith, J. S. Boatwright, N. R. Crouch, E. Figueiredo, L. C. Foxcroft, V. Jarosik, D. M. Richardson, J. Suda, and J. R. U. Wilson. 2013. Hitting the right target: Taxonomic challenges for, and of, plant invasions. AoB Plants 5, plt042. https://doi.org/10.1093/aobpla/plt042

Resh, V. H. and R. T. Cardé. (Editors). 2009. Encyclopedia of Insects. Second Edition. Academic Press. San Diego, California, USA. 1,168 pp.

Roosen-Runge, E. C. 1977. The Process of Spermatogenesis in Animals. Developmental and Cell Biology 5. First Edition. Cambridge University Press. New York, NY, USA. 272 pp.

Rozek, M. 1994. A new chromosome preparation technique for Coleoptera (Insecta). Chromosome Research 2:76-78. https://doi.org/10.1007/BF01539458

Sadílek, D., R. B. Angus, F. Štáhlavský, and J. Vilímová. 2016. Comparison of different cytogenetic methods and tissue suitability for the study of chromosomes in Cimex lectularius (Heteroptera, Cimicidae). Comparative Cytogenetics 10(4):731-752. http://dx.doi.org/10.3897/CompCytogen.v10i4.10681

Sharma, A. K. and A. Sharma. 1980. Chromosome Techniques. Theory and Practice. Butterworth \& Co. (Publishers) Ltd. London, England, UK. 711 pp.

Shibab, S. N. A. 2012. Your Easy Way to Chromosomes. AuthorHouse. Bloomington, Indiana, USA. $384 \mathrm{pp}$.

Soldán, T. and M. Putz. 2000. Karyotypes of some Central European mayflies (Ephemeroptera) and their contribution to phylogeny of the order. Acta Societatis Zoologicae Bohemicae 64:437-445.

Stanyon, R., M. Rocchi, O. Capozzi, R. Roberto, D. Misceo, M. Ventura, M. F. Cardone, F. Bigoni, and N. Archidiacono. 2008. Primate chromosome evolution: Ancestral karyotypes, marker order and neocentromere. Chromosome Research 16:17-39. http://dx.doi.org/10.1007/s10577-007$\underline{1209-\mathrm{Z}}$

Tsoumani, K. T., E. Drosopoulou, P. Mavragani-Tsipidou, and K. D. Mathiopoulos. 2013. Molecular characterization and chromosomal distribution of a species-specific transcribed centromeric satellite repeat from the olive fruit fly, Bactrocera oleae. PLoS ONE 8(11): e79393. http://dx.doi.org/10.1371/journal.pone.0079393

Virkki, N. and J. A. Santiago-Blay. 1997. Chromosome numbers of some Puerto Rican species of leaf beetles (Coleoptera; Chrysomelidae): Biogeographical and evolutionary considerations. Cytobios 90(361):103-131.

White, M. J. D. 1977. Animal Cytology and Evolution. Third Edition. Cambridge University Press. Cambridge, England, UK. 961 pp.

Wolf, K. W. 1996. The structure of condensed chromosomes in mitosis and meiosis of insects. International Journal of Insect Morphology and Embryology 25(1/2):37-62. http://dx.doi.org/10.1016/0020-7322(95)00021-6 